\title{
Sustainability of phosphorus fertilisation: sources and forms of phosphate
}

\section{Sustentabilidade da fertilização fosfatada: origens e formas do fósforo}

\author{
Carmo Horta ${ }^{1,2}$ \\ 1Instituto Politécnico de Castelo Branco, Escola Superior Agrária, Departamento das Ciências da Vida e dos Alimentos, Quinta da Sra. de Mércules, 6001-909 Castelo Branco, Portugal, \\ E-mail:* carmoh@ipcb.pt, autor para correspondência \\ 2CERNAS, Research Centre for Natural Resources, Environment and Society, Quinta da Sra. de Mércules, 6001-909 Castelo Branco, Portugal.
}

http://dx.doi.org/10.19084/RCA15136

Recebido/Received: 2015.09.12

Aceite/Accepted: 2015.10.12

\begin{abstract}
A B S T R A C T
Phosphorus $(\mathrm{P})$, which originates from a non-renewable natural resource, is essential for crop productivity, food security and human health. Despite being a finite resource its use has been increasing consistently over the last few decades. The major use of the phosphate rock is the manufacture of $\mathrm{P}$ fertiliser, agriculture also being the main source for nonpoint source P pollution, which causes the eutrophication of water bodies. Thus, there is great need for a sustainable use of $P$ with special attention to agricultural use, namely P fertilisation. This paper explores P sources and forms that could be phytoavailable and hence used as fertilisers. Current trends in phosphorus fertilisation are also discussed with a focus on approaches to net decrease in phosphate rock exploitation and closure of phosphorous cycle use.
\end{abstract}

Keywords: eutrophication, fertilisers, phosphate rock, soil test phosphorus, struvite

\section{R E S U M O}

O fósforo $(\mathrm{P})$ provém de um recurso natural não renovável e é indispensável para a produtividade agrícola, segurança alimentar e saúde humana. Apesar de ser um recurso finito o seu consumo tem vindo a crescer nas últimas décadas. O principal uso da rocha fosfatada é a produção de adubos fosfatados sendo também a atividade agrícola, a principal fonte de P de origem difusa que causa a eutrofização dos cursos de água. Estes factos enfatizam a necessidade do uso sustentável do P com especial atenção no seu uso agrícola, em particular na fertilização fosfatada. Este artigo aborda as origens e as formas de P que podem ser fitodisponíveis e, deste modo usadas como fertilizantes. São também apresentadas as atuais tendências para uma fertilização fosfatada sustentável, com referência a algumas práticas e tecnologias para alcançar não só uma real diminuição na exploração das rochas fosfatadas, com também para fechar o ciclo de utilização do fósforo.

Palavras-chave: eutrofização, fertilizantes, métodos de quantificação do fósforo, rocha fosfatada, struvite

\section{History and evolution of phosphorus fertilisation}

Phosphorus (P) is an essential nutrient for living beings making up about $0.2 \%$ of a plant's dry weight. $\mathrm{P}$ enters in the food chain taken up by plant roots from soil solution. $\mathrm{P}$ is a component of key molecules such as nucleic acids, phospholipids, and ATP. Therefore is a component of many cell constituents and plays a major role in several key processes, including photosynthesis, respiration, and energy storage and transfer, cell division, and cell enlargement (Marschner, 1995; Schachtman et al., 1998). In addition to other functions animals also require $\mathrm{P}$ for bones and teeth and derive their phosphorus needs from plant products and feed supplements. Thus, an adequate soil $\mathrm{P}$ level is essential not only for crop production but also for food security and human health. 
Generally the content of the native soil available $\mathrm{P}$ is too low to meet crop requirements. Vance et al. (2003) refer that more than $40 \%$ of the world arable soils are deficient in $\mathrm{P}$ and needs fertilisation to increase crop productivity. Records of the use of $P$ fertilisation in agriculture are lost in history and consist of the use of bones, "bird dung" (guano) and manures. One of the most ancient records is the use of guano in Carthage about 200 BC. The first patent of a phosphate fertiliser made by the treatment of bones with sulfuric acid was registered in 1842 by J. Lawes of Britain who subsequently modified his patent to include treatment of mineral phosphates. Liebig noted in 1857 that mineral phosphates could be solubilized with sulfuric acid as readily as bones and thus be made much more effective as fertiliser. In only five years the production of single superphosphate (SSP) reached 200,000 tons per annum in Great Britain (Earl and Aloui, 2011).

The Green Revolution was a period in the mid-20th century (1930-1960) when the productivity of global agriculture increased drastically as a result of new advances and technology transfer. During this time period, new chemical fertilisers have made it possible to supply crops with extra nutrients and, therefore, increase yields. Also synthetic herbicides and pesticides were created contributing also to increase yields. Since that time the production of P mineral fertilisers uses "phosphate rock" $(\mathrm{PR}$ i.e. rock rich in the mineral fluorapatite $\left[\mathrm{Ca}_{5}\left(\mathrm{PO}_{4}\right)_{3} \mathrm{~F}\right]$ and phosphoric acid $\left(\mathrm{H}_{3} \mathrm{PO}_{4}\right)$, which

Table 1 - Phosphate product export distribution (percent based on product tonnes - 2010)

\begin{tabular}{lccc}
\hline Country & \multicolumn{3}{c}{ Phosphate product } \\
\cline { 2 - 4 } & Phosphate rock & Phosphoric acid & DAP $^{\mathbf{1}} / \mathbf{M A P}^{\mathbf{2}}$ \\
& & $\%$ & \\
\hline Morocco & 35 & 48 & 13 \\
Jordan & 15 & - & - \\
Tunisia & - & 11 & - \\
United States & - & 8 & 27 \\
China & - & - & 23 \\
Russia & - & - & 16 \\
Other countries & 50 & 33 & 21 \\
\hline
\end{tabular}

${ }^{1}$ Di-ammonium phosphate; ${ }^{2}$ Mono-ammonium phosphate.

Source: http://www.potashcorp.com/industry_overview/2011/nutrients/25/

Worldwide uses of phosphoric acid (\%)

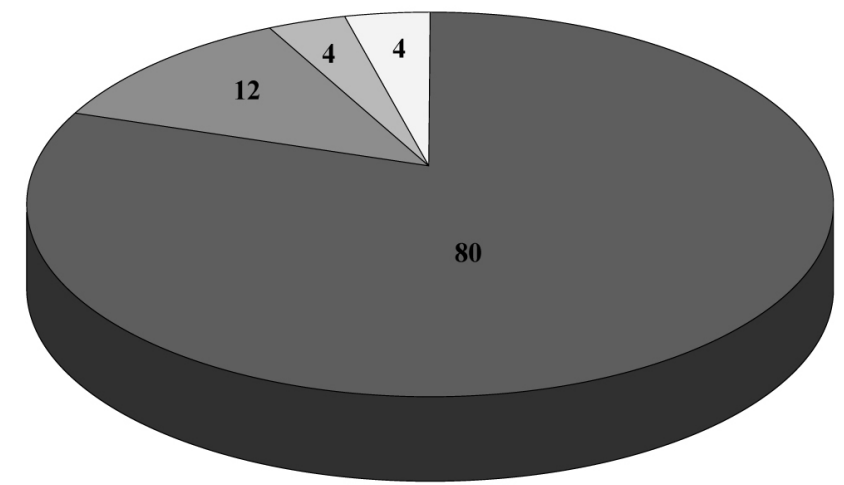

Fertilizer manufacture $\square$ Synthetic detergents $\square$ Animal feeds additive $\square$ Other uses

Figure 1 - Worldwide uses of phosphoric acid (\%)

Source: http://www.essentialchemicalindustry.org/chemicals/phosphoric-acid.html 
comes mainly from the treatment of PR with concentrated sulfuric acid. Single superphosphate was the first commercial P mineral fertiliser and is manufactured from the reaction between sulfuric acid and PR. Whereas triple superphosphate (TSP) fertiliser is produced by the action of concentrated phosphoric acid on ground phosphate rock. Also ammoniated phosphates (mono-ammonium phosphate-MAP and di-ammonium phosphateDAP) are manufactured with phosphoric acid. As we can see in Table 1 Morocco is the main producer of PR and of phosphoric acid whereas US is the main producer of MAP and DAP. Data from 2013 indicates that the world annual production of phosphoric acid was about 38 million tonnes (Ciec, 2013) with $80 \%$ used for the fertiliser manufacture (Figure 1).

Nevertheless, phosphate rock is a finite natural resource and cannot be extracted forever to compensate for use losses. Most PR used in fertiliser production is sedimentary $(>80 \%)$, but igneous deposits are also used and were formed mostly in shield areas and rift zones (Figure 2). Several scarcity of PR (Runge-Metzger, 1995; Cordell et al. 2009; Gilbert, 2009; Cordell et al., 2011).

PR world reserves estimated by the United States Geological Survey (USGS) and by the International Fertiliser Development Center (IFDC) are quite different (Table 1). The IFDC points out that the PR world reserves are much larger than formerly estimated. Indeed some researchers have also been presenting data showing a better scenario about the concerns with PR depletion. They referred that PR reserves could meet demand into the $22^{\text {nd }}$ century, and can be extended well into the $23^{\text {rd }}$ century with assessed use reduction and recycling measures (Van Vuuren et al., 2010; Koppelaar and Weikard, 2013). Nevertheless $95.6 \%$ of world PR reserves are located in only 5 countries having Morocco $85 \%$ of the world PR reserves (Table 2 ). The world distribution of PR reserves also highlights the geopolitical significance of phosphate trade. In Europe hardly no raw $\mathrm{P}$ is available except for very small quantities in Finland. The uncertainty about PR resource availability and consuming in the near future has led to the inclusion of PR on the EU

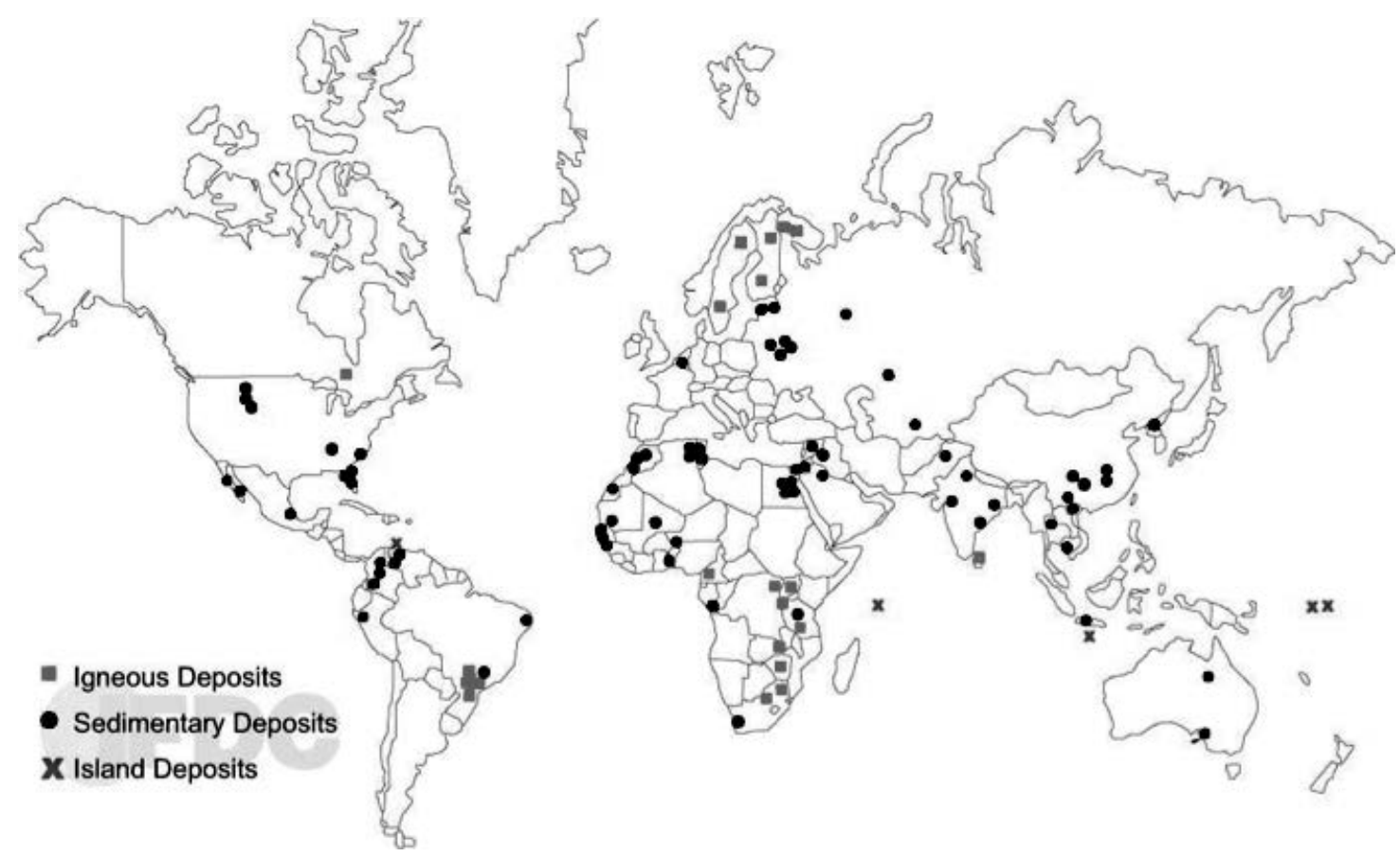

Figure 2 - Location of world phosphorus resources Source: Zapata (2004)

researchers pointed out the concern about the fact that the current exploitation of PR is nearing the "peak production" and this shortly will drive to a
Critical Raw Materials list in 2014. Despite the risks of P resources depletion, FAO (2012) has estimated an increase of the world demand for phosphorus 
Table 2 - Estimated world phosphorus rock reserves and resources $\left(10^{9} \mathrm{~kg}\right)$

\begin{tabular}{|c|c|c|c|c|c|}
\hline \multirow[t]{2}{*}{ Country } & \multicolumn{2}{|c|}{ Mine production } & \multirow{2}{*}{$\begin{array}{c}\text { USGS }^{1}, 2010 \\
\text { estimated } \\
\text { reserves }\end{array}$} & \multirow{2}{*}{$\begin{array}{c}\text { IFDC }^{2} \\
\text { est. reserves }^{3} \\
\text { (product) }\end{array}$} & \multirow{2}{*}{$\begin{array}{c}\text { IFDC }^{2} \\
\text { Estimated } \\
\text { resources }\end{array}$} \\
\hline & 2008 & 2009 & & & \\
\hline Morocco & 25.0 & 24.0 & 5,700 & 51,000 & 170,000 \\
\hline China & 50.7 & 55.0 & 3,700 & 3,700 & 16,800 \\
\hline United States & 30.2 & 27.2 & 1,100 & 1,800 & 49,000 \\
\hline Jordan & 6.3 & 6.0 & 1,500 & 900 & 1,800 \\
\hline Russia & 10.4 & 9.0 & 200 & 500 & 4,300 \\
\hline Other countries & 38.5 & 35.8 & 3,427 & 2,007 & 45,580 \\
\hline $\begin{array}{l}\text { World total } \\
\text { (rounded) }\end{array}$ & 161 & 158 & 16,000 & 60,000 & 290,000 \\
\hline \multicolumn{3}{|c|}{$\begin{array}{l}\text { Estimated longevity in years based on } \\
2008-2009 \text { average production level }\end{array}$} & 100 & 376 & - \\
\hline
\end{tabular}

${ }^{1}$ USGS - United States Geological Survey;

IFDC - International Fertiliser Development Center:

${ }^{3}$ Reserves: materials that can be economically produced at the present time using technology;

${ }^{4}$ Resources: include reserves and any other materials of interest that are not reserves.

Source: International Plant Nutrition Institute http://www.ipni.net/ipniweb/portal.nsf/0/02d5d56d777313b2062577ce0069a3a8/\$file/p\%20fert\%20tech\%2011\%2010\%20

2010.pdf

fertiliser in the period 2012-2016 (from 41,525 thousand tonnes in 2012 to 45,013 in 2016), with an annual growth rate of $2 \%$ but when considering only Europe this rate increases to $2.5 \%$. The annual growth rate for the same period in Europe for $\mathrm{N}$ and $\mathrm{K}$ was $1.3 \%$ and $2 \%$ respectively.

Agricultural P uses above plant needs, mainly in developed countries, has resulted in the accumulation of $\mathrm{P}$ in soils with resulting $\mathrm{P}$ losses to drainage and runoff waters and sediments, leading to the eutrophication of water bodies (Sharpley and Tunney, 2000; Carpenter, 2005; Kleinman et al., 2011). Therefore sustainability of $\mathrm{P}$ fertilisation needs the implementation of innovative technological approaches on $\mathrm{P}$ and crop productivity management.

\section{Sources of phosphorus}

\section{Mineral fertilisers from phosphate rocks}

Since de middle of $19^{\text {th }}$ century the $\mathrm{P}$ fertilisers commonly used have been the superphosphates and according to their $\mathrm{P}$ level they are called single (SSP) or triple (TSP).

SSP contains 7 to $9 \%$ of $\mathrm{P}$ (16 to $20 \% \mathrm{P}_{2} \mathrm{O}_{5}$ ), 18 to $21 \%$ of $\mathrm{Ca}$ and 11 to $12 \%$ of $\mathrm{S}$, and results from the reaction of $\mathrm{PR}$ with sulfuric acid:
$2 \mathrm{Ca}_{5}\left(\mathrm{PO}_{4}\right)_{3} \mathrm{~F}+7 \mathrm{H}_{2} \mathrm{SO}_{4}+3 \mathrm{H}_{2} \mathrm{O} \rightarrow 7 \mathrm{CaSO}_{4}+$ $3 \mathrm{Ca}\left(\mathrm{H}_{2} \mathrm{PO}_{4}\right)_{2} \cdot \mathrm{H}_{2} \mathrm{O}+2 \mathrm{HF} \quad[E q .1]$

TSP results from the reaction of $\mathrm{PR}$ with phosphoric acid, and contains $\approx 19 \%$ of $\mathrm{P}\left(45 \% \mathrm{P}_{2} \mathrm{O}_{5}\right)$ with $\leq 3 \%$ of $\mathrm{S}$ and $15 \%$ of $\mathrm{Ca}$. The TSP chemical formula is $\mathrm{Ca}\left(\mathrm{H}_{2} \mathrm{PO}_{4}\right)_{2} \cdot \mathrm{H}_{2} \mathrm{O}$.

The production of superphosphates has declined since the 1980s in favour of ammoniated phosphates as costs of producing TSP can be higher than ammoniated phosphates, making the economics for TSP less favourable in some situations. These fertilisers could be di-ammonium (DAP: 18-46-0) or mono-ammonium phosphates (MAP: 11-52$0)$. Ammoniated phosphates are formed when a solution of phosphoric acid is added to ammonia until the solution is distinctly acidic. MAP has the chemical formula of $\mathrm{NH}_{4} \mathrm{H}_{2} \mathrm{PO}_{4}$ and DAP is $\left(\mathrm{NH}_{4}\right)_{2} \mathrm{HPO}_{4}$. DAP is currently the major $\mathrm{P}$ dry fertiliser used. There are also in the market NPK fertilisers obtained by adding $\mathrm{K}$ salts to DAP, MAP, SSP or STP. NPK fertilisers can also be obtained from nitrophosphates which is originated after treatment of PR with $\mathrm{HNO}_{3}$. There are also in the market $\mathrm{P}$ fertilisers with soluble $\mathrm{P}$ forms and liquid P solutions. 


\section{Organic wastes as $P$ sources}

Animal manures and other agro-wastes as well as treated wastewaters, sewage sludge, anaerobic digestates from biogas production plants are

Table 3 - Phosphorus and nitrogen contents (\%) and N/P ratio of different organic wastes used as fertilisers in the Portuguese region of "Beira Interior Centro"

\begin{tabular}{lccccccc}
\hline & \multicolumn{3}{c}{$\begin{array}{c}\text { Sewage sludge } \\
(\mathrm{n}=42)\end{array}$} & & \multicolumn{3}{c}{$\begin{array}{c}\text { Cattle slurry } \\
(\mathrm{n}=7)\end{array}$} \\
\cline { 2 - 3 } \cline { 7 - 8 } & $\mathbf{P}_{\mathbf{2}} \mathbf{O}_{\mathbf{5}}$ & $\mathbf{N}$ & $\mathbf{N} / \mathbf{P}$ & & $\mathbf{P}_{\mathbf{2}} \mathbf{O}_{\mathbf{5}}$ & $\mathbf{N}$ & $\mathbf{N} / \mathbf{P}$ \\
\hline Mean & 1.67 & 3.79 & 7 & & 0.034 & 2.85 & 2471 \\
Median & 1.64 & 3.52 & 5 & & 0.010 & 3.24 & 666 \\
Maximum & 5.14 & 5.07 & 42 & & 0.160 & 6.22 & 7133 \\
Minimum & 0.17 & 1.47 & 2 & & 0.002 & 0.09 & 6 \\
$\mathrm{SD}^{1}$ & 0.90 & 1.41 & 7 & & 0.062 & 2.59 & 3022 \\
$\mathrm{CV}^{2}(\%)$ & 54 & 37 & 100 & & 102 & 91 & 122 \\
\hline
\end{tabular}

1 Standard deviation;

${ }^{2}$ coefficient of variation $=[(\mathrm{SD} /$ mean $) \times 100]$

Source: Horta and Torrent (2010)

common organic wastes used in agricultural soil with fertiliser value. These organic wastes contain different levels and forms of phosphorus which lead to also different agronomic effects. Tables 3 and 4 shows $\mathrm{P}$ and $\mathrm{N}$ content of some organic wastes and composts obtained in Portuguese region "Beira Interior Centro" and Table 5 shows the $\mathrm{P}$ and $\mathrm{N}$ content indicated in the Portuguese Book of Best Agricultural Practices (BAP) for a rationale nitrogen planning fertilisation.

$\mathrm{P}$ content and $\mathrm{N} / \mathrm{P}$ ratio in organic wastes and composts differs greatly not only between them but particularly in relation to the same organic waste or compost (Tables 3 and 4). These feature leads to some constraints in fertilisation strategy. If the amount of the organic waste application is calculated to meet the existing BAP to prevent

Table 4 - Phosphorus and nitrogen contents (\%) and N/P ratio of different composts used as fertilisers in the Portuguese region of "Beira Interior Centro"

\begin{tabular}{|c|c|c|c|c|c|c|c|c|c|}
\hline & \multicolumn{3}{|c|}{$\begin{array}{c}\text { Compost } \mathbf{S S}^{3} \\
(\mathrm{n}=5)\end{array}$} & \multicolumn{3}{|c|}{$\begin{array}{l}\text { Cattle manure } \\
\text { compost }(\mathrm{n}=4)\end{array}$} & \multicolumn{3}{|c|}{$\begin{array}{c}\text { Compost MSW } \\
(\mathrm{n}=5) \\
\end{array}$} \\
\hline & $\mathbf{P}_{2} \mathbf{O}_{5}$ & $\mathbf{N}$ & $\mathbf{N} / \mathbf{P}$ & $\mathbf{P}_{2} \mathrm{O}_{5}$ & $\mathbf{N}$ & $\mathbf{N} / \mathbf{P}$ & $\mathbf{P}_{2} \mathbf{O}_{5}$ & $\mathbf{N}$ & $\mathbf{N} / \mathbf{P}$ \\
\hline Mean & 0.66 & 1.61 & 8 & 1.39 & 2.76 & 12 & 0.28 & 1.77 & 18 \\
\hline Median & 0.57 & 1.76 & 5 & - & - & 9 & 0.29 & 1.71 & 14 \\
\hline Maximum & 1.38 & 2.08 & 14 & 2.45 & 3.99 & 28 & 0.36 & 2.1 & 37 \\
\hline Minimum & 0.30 & 0.94 & 3 & 0.33 & 1.53 & 1 & 0.10 & 1.6 & 12 \\
\hline $\mathrm{SD}^{1}$ & 0.38 & 0.38 & 5 & 1.49 & 1.74 & 10 & 0.10 & 0.20 & 10 \\
\hline $\mathrm{CV}^{2}(\%)$ & 58 & 24 & 60 & 108 & 63 & 83 & 37 & 16 & 54 \\
\hline
\end{tabular}

1Standard deviation;

${ }^{2}$ Coefficient of variation $=[(\mathrm{SD} / \mathrm{mean}) \star 100]$;

${ }_{3}^{3 S S}$ - Compost from sewage sludge and sawdust;

$4 \mathrm{MSW}$ - Compost from municipal solid wastes.

Source: Horta and Torrent (2010)
Table 5 - Phosphorus and nitrogen levels of different organic wastes and composts used as fertilisers referred on Portuguese Book of Best Agricultural Practices

\begin{tabular}{lcc}
\hline Organic residue or Compost & $\mathbf{P}_{\mathbf{2}} \mathbf{O}_{\mathbf{5}}$ total & N total \\
\hline Sewage sludge (\%) & 4.3 & 3.3 \\
Cattle slurry $\mathrm{kg} \mathrm{m}^{-3}$ & $1.2-2.1$ & $5.0-3.7$ \\
Swine slurry $\mathrm{kg} \mathrm{m}^{-3}$ & 3.5 & 6.0 \\
Poultry manure $\mathrm{kg} /$ ton & $18-25$ & $40-20$ \\
Horse manure $\mathrm{kg} /$ ton & 2.5 & 5.0 \\
Manure of sheep and goats $\mathrm{kg} / \mathrm{ton}$ & 2.5 & 5.5 \\
Compost MSW $(\%)$ & 1.4 & 1.8 \\
\hline
\end{tabular}

1Source: Ministério da Agricultura, do Desenvolvimento Rural e das Pescas (1997)

nitrogen losses, in some cases there are a marked unbalance in $\mathrm{N} / \mathrm{P}$ ratio e.g. $\mathrm{N} / \mathrm{P}=2$ which is quite different from the $\mathrm{N} / \mathrm{P}$ ratio to meet crop needs $(\mathrm{N} / \mathrm{P}=7-11)$. This generally accounts for an accumulation of $\mathrm{P}$ in soil. On the other hand if the amount of residue is estimated to meet the $\mathrm{P}$ needs of crops it is possible in some cases to apply $\mathrm{N}$ in excess e.g. $\mathrm{N} / \mathrm{P}=42$. Therefore, when using organic wastes or composts as fertilisers is advisable to know its own chemical composition to do an adequate fertilisation planning instead of using published data.

\section{Fertilisers manufactured from organic wastes}

The inclusion of P in the EU Critical Raw Materials list in 2014 pointed to the need of recover and reuse $P$ in wastes namely in food wastes, in wastewater and sludge and in manures or livestock effluents. Regarding to mineral phosphorus requirements Europe has a high import dependency above 90\% of its needs. In Switzerland for example, a quantity equalling of $15 \%$ of Europe's mineral $\mathrm{P}$ demand has being wasted as disposed sewage sludge and its ashes (P-REX policy brief in Scope newsletter, March 2015). There are currently technological processes to remove nitrogen and phosphorus from wastewater by precipitating them as the mineral struvite (magnesium ammonium phosphate $\left.\mathrm{NH}_{4} \mathrm{MgPO}_{4} \cdot 6 \mathrm{H}_{2} \mathrm{O}\right)$ which contains $5 \%$ of $\mathrm{N}, 28 \%$ of $\mathrm{P}_{2} \mathrm{O}_{5}$ and $10 \%$ of $\mathrm{Mg}$. Struvite was firstly known to be a "problem" material by wastewater operators. Frequently it is formed in sewage sludge digesters and liquid manure handling systems, where it causes blockages (Doyle and Parson, 2002; Mohan et al., 2011), but nowadays it becomes a product that could be of economic interest. The good agronomic properties of struvite are known since the middle of 20th century (Bridger et al., 1961). The use of technology to separate nutrients from wastewater, sewage sludge and its ashes and after 
that use these mineral nutrients to make fertilisers will have the benefit to overcome limitations with diffuse contaminants, such as pharmaceuticals and organic chemicals arising from the direct application of sewage sludge and ashes on arable land. There are approximately 10 companies/ water utilities (legal entities) producing recovered struvite from wastewater today in Europe (scope newsletter, March 2015). In addition, a proposal for "EU fertiliser criteria for recovered struvite" to include in the EU Fertiliser Regulation revision and/or struvite End-of-Waste criteria is now in discussion and validation (Proposed EU fertiliser regulation criteria for recovered struvite, 2015).

A further way of reusing nutrients has been the production of organic fertilisers after treatment of manures. The Flemish Coordination Centre for Manure Processing is an example of P recycled from manures. In this case the manure of pig, poultry and cattle manure or digestates undergoes liquid/ solid separation, drying, composting, nitrogen removal or ammonia recovery and post treatment (e.g. addition of other nutrients, granulation) to produce an organic fertiliser, adapted for use on arable crops, so recycling both phosphorus and organic carbon. Flanders exports manures to North France and also exports granulated poultry manure to Asia and the Middle East. In total some 24,000 tonnes of phosphorus (P) are exported and recycled annually (Scope newsletter, March 2015).

These are some innovative strategies to improve the sustainability of $\mathrm{P}$ fertilisation contributing to close the cycle of $\mathrm{P}$ use.

\section{Phosphorus forms and P phytoavailability in fertilisers}

Regardless of the P sources, fertilisers should have $\mathrm{P}$ in available forms for plant uptake. Availability depends not only of $\mathrm{P}$ soil dynamics and of crop uptake characteristics but firstly it depends on the dissolution kinetics of the chemical forms of $\mathrm{P}$ in the fertilisers. $P$ forms in the fertilisers that are soluble in water are in principle high available to plants. Nevertheless, the soluble P in soil solution could undergo rapid immobilisation by sorption onto soil mineral surfaces (oxi-hydroxides of Fe and $\mathrm{Al}$, clay minerals and calcite), or by incorporation into soil metal-organic matter complexes (Gerke and Hermann, 1992; Matar et al., 1992; Frossard et al., 1995; Torrent, 1997; Borggaard et al., 2004). So, the concentration of orthophosphate-P in the soil solution is basically controlled by adsorption/ desorption and precipitation/dissolution processes and also by the immobilisation and mineralisation of organic P forms. Labile P forms are the amount of $\mathrm{P}$ in the soil solid phase that will readily resupply $\mathrm{P}$ in soil solution. Single superphosphate $\left[\mathrm{Ca}\left(\mathrm{H}_{2} \mathrm{PO}_{4}\right)_{2} \cdot \mathrm{H}_{2} \mathrm{O}, \mathrm{CaSO}_{4} \cdot \mathrm{nH}_{2} \mathrm{O}(\mathrm{n}=0 ; 0.5\right.$ or 2.0$\left.)\right]$ and triple superphosphate $\left[\mathrm{Ca}\left(\mathrm{H}_{2} \mathrm{PO}_{4}\right)_{2} \cdot \mathrm{H}_{2} \mathrm{O}\right]$ have 85 and $87 \%$ of $\mathrm{P}$ forms water soluble respectively. Mono-ammonium phosphate $\left(\mathrm{MAP}-\mathrm{NH}_{4} \mathrm{H}_{2} \mathrm{PO}_{4}\right)$ have a lower $\mathrm{P}$ water solubility of $50 \%$ as it can content re-precipitated apatite $\left[\left(\mathrm{NH}_{4} \mathrm{H}_{2} \mathrm{PO}_{4}\right.\right.$ $\left.\left.\mathrm{CaHPO}_{4},\left(\mathrm{NH}_{4}\right)_{2} \mathrm{HPO}_{4}\right)\right]$ but in di-ammonium phosphate $\left[\mathrm{DAP}-\left(\mathrm{NH}_{4}\right)_{2} \mathrm{HPO}_{4}\right] \mathrm{P}$ forms are $100 \%$ water soluble (Engelstad and Terman, 1980). In P mineral fertilisers the standard method to evaluate $P$ availability is by the solubility of $\mathrm{P}$ in ammonium citrate solution (AOAC, 1975). The solubility of $\mathrm{P}$ in $2 \%$ citric acid is also used to evaluate fertiliser value of basic slag a by-product of steelmaking $(<2 \%$ of P solubility in water, Ca- silico-carnotite) or $\mathrm{PR}(<1 \%$ of P solubility in water, carbonate apatite $\left[\mathrm{Ca}_{5}\left(\mathrm{PO}_{4}\right)_{3}(\mathrm{OH}, \mathrm{F}, \mathrm{Cl})\right]$ (Engelstad and Terman, 1980). $\mathrm{P}$ forms that are soluble in citric acid accounts for slow release of $\mathrm{P}$ from the fertilisers.

In composts and livestock manures $\mathrm{P}$ forms differs widely not only between different organic products but also between the same types of product. Nevertheless in these organic products $\mathrm{P}$ is mainly in inorganic form $(\mathrm{Pi})$ and accounts approximately for $90 \%$ of total P. Frossard et al. (2002) evaluated Pi forms by a sequential extraction (Traoré et al., 1999) and by isotopic exchange experiments in 16 composts obtained in Switzerland mainly from solid urban organic wastes (SUOW), woody wastes (WW) and farmyard manure plus SUOW or farmyard manure plus WW. The results showed that the composts contain relative large concentrations of rapidly available $\mathrm{Pi}$ and that a fraction of the slowly or non-exchangeable $\mathrm{Pi}$ is bound to $\mathrm{Ca}$ in the form of apatite or octacalcium phosphates. These authors concluded that from an agronomic point of view the fraction bound to $\mathrm{Ca}$ of compost-P will probably have a low availability to plants in neutral and alkaline soils.

Also, in six organic residues produced in Portugal and evaluated by the same P sequential extraction Pi ranges from 80 to $99 \%$ of total P (Horta, 2015). The organic residues under study were four composts obtained from the mixture of sewage sludge plus saw dust and two dry fractions from poultry or 
pig slurries. In these composts the majority of Pi is in highly available forms whilst in the livestock slurries the main forms are $\mathrm{Pi}-\mathrm{Ca}$ species which could have lower availability. The partition of $\mathrm{Pi}$ forms in struvite and TSP by the same sequential procedure was also done. The results show that $32 \%$ and $86 \%$ of readily available forms of $\mathrm{Pi}$ are present in struvite and TSP respectively and that the slowly available Pi forms accounts for $26 \%$ in struvite and only $13 \%$ in TSP. These results suggest that the partition of Pi forms in composts, animal manures and mineral fertilisers will influence the agronomic efficiency of $\mathrm{P}$. The phytoavailability of these different $\mathrm{P}$ forms will depend also on soil properties (e.g. $\mathrm{pH}$ ) and crop uptake characteristics.

Nevertheless, fertilisation of ryegrass (Lolium perenne L.) with animal manures (cattle manure compost, slurry dry fractions one of poultry and another from pig) or $\mathrm{P}$ mineral fertiliser (TSP) using the same amount of $P$ in fertilisation $(50 \mathrm{~kg}$ $\mathrm{P} \mathrm{ha}^{-1}$ ) showed that animal manures were a source of phytoavailable P (Horta et al., 2014a). In addition higher yields were obtained when using animal manures as a $\mathrm{P}$ source compared with equivalent amounts of mineral fertiliser (Reddy et al. 1999, 2000; Whalen et al., 2000; Horta et al., 2014a). Experiments with struvite show that it's a source of $\mathrm{P}$ to crops with a $\mathrm{P}$ slow release effect which is a benefit for pastures (Thompson et al., 2012; Katanda et al., 2013; Cerrillo et al., 2015). Nevertheless to use struvite as a fertiliser is still needed more research to develop efficiency and scale of recovered struvite from sewage and to formulate appropriate fertilisers (P-REX policy brief, March 2015).

\section{Current phosphorus fertilisation strategy}

Until now $\mathrm{P}$ fertilisation has been done considering the information provided by soil $\mathrm{P}$ tests with agronomic meaning and thus based on fertility classes or indexes associated to the ranges in the amount of soil available P (e.g. Bray, 1945; Olsen et al., 1954; Egnér et al., 1960; Mehlich, 1984). The amount of $\mathrm{P}$ extracted for each of these tests is correlated with P uptake by crops so it means in principle that the amount of $P$ quantified by the test is phytoavailable. The currently overfertilisation observed in the majority of arable land in developed countries should have multiple sources.

First the suitability of $\mathrm{P}$ tests to soil properties and soil $\mathrm{P}$ dynamics. The amount of $\mathrm{P}$ in solution is the result of equilibrium between the activity of soil solution $\mathrm{P}$ (intensity factor) and $\mathrm{P}$ sorbed onto the soil solid phase (capacity factor). Some tests are closer to quantify the capacity factor and others the intensity factor. Therefore a chemical extraction solution has not the ability of put together these dynamic relationships resulting information that should be regarded together with some other soil properties and even with crop uptake characteristics (Horta and Torrent, 2010).

A second feature is the suitability of the referred $\mathrm{P}$ tests concerning the soils where fertilisation was done with manures and others organic wastes. After the addition of these fertilisers the partition of $\mathrm{P}$ by different soil $\mathrm{P}$ forms reflects the composition of the organic wastes and the soil properties (Sharpley at al., 2004). The chemical solutions used by soil $\mathrm{P}$ tests could not have, in these soils, a good correlation with crop P uptake (Horta et al., 2014b) and therefore they have limitations for $\mathrm{P}$ fertiliser planning. As said previously in many countries in Europe the restriction in applying manures to the soil is based on its $\mathrm{N}$ content which have in some cases N/P ratios lower than the crop needs leading to $\mathrm{P}$ soil accumulation.

In Portugal as well as in other countries soil $\mathrm{P}$ status is characterised by a high level in intensive agricultural systems and a $\mathrm{P}$ deficit in extensive agricultural systems (Torrent et al., 2007; Horta and Torrent, 2010). The higher levels of soil P did not result in an increase in $\mathrm{P}$ agronomic efficiency, $\mathrm{FAO}$ (2006) refer that only $15 \%$ to $30 \%$ of $\mathrm{P}$ in fertiliser is taken up by crops, often because fertilisers are applied far in excess of plant demand. Childers et al. (2011) refer that only about $20 \%$ of all mined $\mathrm{P}$ is actually consumed in food, the remaining $80 \%$ is lost from the human P cycle. The overfertilised soils have exceeded its P sorption capacity and behave as "hotspots" contributing to nonpoint source pollution leading to long-term eutrophication of water bodies (Heckcrath et al., 1995; McDowell et al., 2015). However even the extensive agricultural systems (e.g. pastures, outdoor livestock production) characterised by low inputs of production factors such as mineral fertilisers could have also "hotspots" with high soil P levels due to continuous input of feed and animal excretions (Salomon et al., 2007; Horta et al., 2012). These areas are also net contributors to diffuse $\mathrm{P}$ emissions at catchment scale. There are also in some countries e.g. Portugal, fertilisation recommendations target to the different crops (e.g. cereals, horticultural 
crops, pastures, ornamentals) based on field experiments. Even these recommendations have sometimes an overestimation of $\mathrm{P}$ fertilisation. In addition to soil $\mathrm{P}$ status and crop needs it should also be considered the edaphic conditions as soil properties, topographic location and climate for an adequate fertiliser planning.

\section{Trends in phosphorus fertilisation}

Sustainability of $\mathrm{P}$ fertilisation will require a paradigm shift in the current $\mathrm{P}$ and crop productivity management. Therefore to achieve $\mathrm{P}$ sustainability not only a net decrease in PR exploitation is needed but it is also crucial to close the cycle of phosphorus use. In order to meet this objective Withers et al. (2015) have articulated five key $R$ strategies $(5 R)$ to improve $\mathrm{P}$ management: Realign $\mathrm{P}$ inputs more precisely to maximize efficiency, Reduce P losses to the oceans, Recycle more $\mathrm{P}$ in bioresources, Recover and reuse $\mathrm{P}$ from wastes and Redefine $\mathrm{P}$ requirements in the food chain.

In order to Realign $\mathrm{P}$ inputs it has been paid some attention to the role and significance of soil organic matter and microorganisms in promoting better soil conditions for healthy plants and better nutrient uptake. So, nowadays the addition of humic substances, seaweed and beneficial microorganisms to some compound fertilisers are also done. These fertilisers provide an increase in crop uptake of nutrients by stimulating the crop metabolism and also the microbial activity on the mineralisation of soil organic-P compounds. Also products with only beneficial microorganisms such as Azotobacter, Azospirillus, Bacilus, Pseudomonas, Rhizobium and some genus of Cyanobacteria are also in the market. Mycorrhizae a mutualistic relationship between plant roots and fungus of the genus Ascomycetes, Basidiomycetes and Glomeromycota, improve nutrient crop uptake, mainly soil P. The increase in soil P uptake occurs due to phosphatase excretion by the fungus promoting organic P mineralisation and also by the increase in the volume of scavenged by the fungus bypassing Pi depletion in rhizosphere (Smith and Read, 1997; Smith et al., 2011). Thus, some research trends are about soil inoculation with hyphae of mycorrhizal fungus or the use of seeds with the addition of phosphatase enzymes. Nevertheless the increase in better biotic conditions in soils improving agricultural practices to increase the organic matter in soil and promote the development of soil microorganisms is a cycle that will enhance soil fertility and P uptake saving $\mathrm{P}$ fertilisers.

Recover and reuse $\mathrm{P}$ from wastes namely to close the cycle of anthropogenic P use could be achieve either by a "traditional approach" and in this case the objective is to reuse the $\mathrm{P}$ added to organic wastes (e.g. sewage sludge, livestock slurries, digestates, ashes) by the use of these products as fertilisers or by an innovative approach using the organic residues to obtain by technological processes some nutrients such as $\mathrm{N}, \mathrm{P}, \mathrm{K}$ and $\mathrm{Ca}$. In this case struvite is a good example because there are now some enterprises in Europe producing struvite from sewage sludge and other wastes. This product could be considered both as a fertiliser ( $5 \% \mathrm{~N}, 28 \% \mathrm{P}_{2} \mathrm{O}_{5}$ and $10 \% \mathrm{Mg}$ ) and either as a raw material (ingredient) for further fertiliser production. This innovative perspective changes the approach to P sustainability as it creates a new market aiming to produce safe fertilisers from organic wastes that are produced locally but can be used globally. Other $R$ strategies concerns about exploitation of legacy $\mathrm{P}$. Legacy $\mathrm{P}$ is the $\mathrm{P}$ that has accumulated in soils from past inputs of fertilisers and manures. These $\mathrm{P}$ forms in arable soils are a secondary source of $\mathrm{P}$ for crop uptake. So, legacy $\mathrm{P}$ could substitute manufactured fertilisers help to preserve critical reserves of finite phosphate rock and its uptake will gradually improve water quality (Rowe et al., 2015). Also, plant breeding to achieve a better use of soil $\mathrm{P}$ and improvement of technologies as precision farming are now some trends to get sustainability of P fertilisation.

\section{References}

AOAC (1975) - Official methods of analysis (2nd ed.). Washington D.C., Association of Official Agricultural Chemists, 832 p.

Borggaard, O.K.; Raben-Lange, B.; Gimsing, A.L. and Strobel, B.W. (2004) - Influence of humic substances on phosphate adsorption by aluminum and iron oxides. Geoderma, vol. 127, n. 3-4, p. 270-279.

http://dx.doi.org/10.1016/j.geoderma.2004.12.011

Bray, R.H. and Kurtz, L.T. (1945) - Determination of total, organic, and available forms of phosphorus in soils. Soil Science, vol. 59, n. 1, p. 39-45. http://dx.doi.org/10.1097/00010694-194501000-00006

Bridger, G.L.; Salutsky, M.L. and Starosika, R.S. (1961) - Metal ammonium phosphates as 
fertilisers. In: 140th Meeting of the American Chemical Society, Chicago, USA, p. 1-19.

Carpenter, S.R. (2005) - Eutrophication of aquatic ecosystems: bistability and soil phosphorus. Proceedings of the National Academy of Sciences of the USA, vol. 102, n. 29, 10002-10005.

http://dx.doi.org/10.1073/pnas.0503959102

Cerrillo, M.; Palatsi, J.; Comas, J.; Vicens, J. and Bonmatí, A. (2015) - Struvite precipitation as a technology to be integrated in a manure anaerobic digestion treatment plant - removal efficiency, crystal characterization and agricultural assessment. Journal of Chemical Technology and Biotechnology, vol. 90, n. 6, p. 1135-1143. http://dx.doi.org/10.1002/jctb.4459

Ciec (2013). The essential chemical industry online. The University of York. [cited 2015-09-16].

http://www.essentialchemicalindustry.org/ chemicals/phosphoric-acid.html

Childers, D.L.; Corman, J.; Edwards, E. and Elser, J.J. (2011) - Sustainability challenges of phosphorus and food: Solutions from closing the human phosphorus cycle. Bioscience, vol. 61, n. 2, p. 117-124.

http://dx.doi.org/10.1525/bio.2011.61.2.6

Cordell, D.; Drangert, J.-O. and White, S. (2009) - The story of phosphorus: global food security and food for thought. Global Environmental Change, vol. 19, n. 2, p. 292-305.

http://dx.doi.org/10.1016/j.gloenvcha.2008.10.009

Cordell, D.; White, S. and Lindström, T. (2011) - Peak phosphorus: the crunch time for humanity? The Sustainability Review, vol. 2, n. 2, 4 April, 2011. [cited 2015-09-16].

https://thesustainability review.org/peakphosphorus-the-crunch-time-for-humanity/1018

Doyle, J.D. and Parsons, S.A. (2002) - Struvite formation, control and recovery. Water Research, vol. 36, n. 16, p. 3925-3940. http://dx.doi.org/10.1016/S0043-1354(02)00126-4

Earl, A. and Aloui, M. B. (2011) - Phosphoric acid technology - History, evolution \& future perspectives. Plenary lecture presented at Symphos 2011, Marrakech, May 2011. [cited 201506-10].

http://ww w.kemworks.com/library/ uploads/documents/549D387A-9B63-2CE0264CD94D2D207AA9-P1104\%20History\%20 of $\% 20$ Phosphoric\%20Acid $\% 20$ Technology.pdf

Egnér, H.; Riehm, H. and Domingo, W.R. (1960) - Untersuchungen iber die chemische Bodenanalyse als Grundlag fur die Beurteilunger des Nahrstoffzustandes der
Boden, II: Chemische Extractionsmethoden zur Phosphor, und Kalium-bestimmung. Kunglia Lantbrukshogskolans Annaler, vol. 26, p. 199-215.

Engelstad, O.P. and Terman, G.L. (1980) - Agronomic effectiveness of phosphate fertilisers. In: Khasawnach, F.E.; Sample, E.C. and Kamprath, E.J. (Eds.) - The role of phosphorus in agriculture. Madison, Winsconsin, ASA-CSSA-SSA, p. 311332.

FAO (2006) - Plant nutrition for food security: A guide for integrated nutrient management. FAO Fertiliser and Plant Nutrition Bulletin 16. Rome, Food and Agriculture Organization of the United Nations, $348 \mathrm{p}$.

FAO (2012) - Current world fertiliser trends and outlook to 2016. Rome, Food and Agriculture Organization of the United Nations, $43 \mathrm{p}$.

Frossard, E.; Brossard, M.; Hedley, M.J. and Metherell, A. (1995) - Reactions controlling the cycling of $\mathrm{P}$ in soils. In: Tiessen, H. (Ed.) Phosphorus in the global environment. New York, John Wiley \& Sons, p. 107-137.

Frossard, E.; Skrabal, P.; Sinaj, S.; Bangerter, F. and Traore, O. (2002) - Forms and exchangeable of inorganic phosphate in composted solid organic wastes. Nutrient Cycling in Agroecossystems, vol. 62, n. 2, p.103-113. http://dx.doi.org/10.1023/A:1015596526088

Gerke, J. and Hermann, R. (1992) - Adsorption of orthophosphate to humic-Fe-complexes and to amorphous Fe-oxide. Zeitschrift für Pflanzenernährung und Bodenkunde, vol.155, n. 3, p. 233-236. http://dx.doi.org/10.1002/jpln.19921550313

Gilbert, N. (2009) - The disappearing nutrient. Nature, vol. 461, n. 8, p. 716-718.

http://dx.doi.org/10.1038/461716a

Heckrath, G.; Brookes, P.C.; Poulton, P.R. and Goulding, K.W.T. (1995) - Phosphorus leaching from soils containing different phosphorus concentrations in the Broadbalk experiment. Journal of Environmental Quality, vol. 24, n. 5, p. 904-910.

http://dx.doi.org/10.2134/jeq1995.004724250 02400050018x

Horta, M.C. (2015) - Disponibilidade em fósforo de fertilizantes orgânicos e adubos fosfatados. In: Livro de resumos do Encontro Anual das Ciências do Solo, Proteger as Funções do Solo Assegurar a Vida da Terra, EACS 2015, 24 e 25 junho, Castelo Branco, p. 23.

Horta, C.; Batista, M.; Roque, N. and Almeida, J. (2012) - Efeitos ambientais da produção de suínos 
ao ar livre: evolução e distribuição espacial das formas de $\mathrm{P}$ no solo e perdas de $\mathrm{P}$ na água de drenagem. Revista de Ciências Agrárias, vol. 35, n. 1, p. 36-48.

Horta, C.; Ribeiro, P.; Batista, M.; Carneiro, J.P.; Duarte, A.; Roboredo, M.; Torrent, J. and Sharpley, A. (2014a) - Animal manures applied to soil: Phosphorus bioavailability, losses to water and erosion. Sustainable Phosphorus Summit, 1-3 september, Montpellier, France, p. 22.

Horta, C.; Ribeiro, P.; Batista, M.; Carneiro, J.P.; Roboredo, M. and Torrent, J. (2014b) - Valorização agrícola de resíduos orgânicos de pecuária: avaliação da fitodisponibilidade em fósforo. In: Macías, F., Díaz-Raviña, M. and Barral, M. T. (Eds.) - Retos y Oportunidades en La Ciencia del Suelo. VI Congresso Ibérico da Ciência do Solo, 23-25 junho, Santiago de Compostela, Spain, p. 319-322.

Horta, M.C. and Torrent, J. (2010) - Dinâmica do fósforo no solo. Perspectiva agronómica e ambiental. Castelo Branco, Portugal, Edições IPCB, 97 p.

Katanda, Y.; Zvomoya, F.; Flaten, D.N. and Cicek, N. (2013) - Phosphorus use efficiency of canola fertilized with struvite extracted from liquid hog manure. In: ASA, CSSA and SSSA International Meetings. 3-6 November, 2013, Florida, USA.

Kleinman, P.J.A.; Sharpley, A.N.; McDowell R.W.; Flaten, D.N.; Buda, A.R.; Tao, L.; Bergstrom, L. and Zhu, Q. (2011) - Managing agricultural phosphorus for water quality protection: principles for progress. Plant and Soil, vol. 349, n. 1, p. 169-182.

http://dx.doi.org/10.1007/s11104-011-0832-9

Koppelaar, R.H.E.M. and Weikard, H.P. (2013) - Assessing phosphate rock depletion and phosphorus recycling options. Global Environmental Change, vol. 23, n. 6, p. 1454-1466. http://dx.doi.org/10.1016/j.gloenvcha.2013.09.002

Marschner, H. (1995) - Mineral nutrition of higher plants. 2nd Ed. London, Academic Press, 889 p.

Matar, A.; Torrent, J. and Ryan, J. (1992) - Soil and fertiliser phosphorus and crop responses in the dryland Mediterranean zone. Advances in Soil Science, vol. 18, p. 81-146.

http://dx.doi.org/10.1007/978-1-4612-2844-8_3

McDowell, R.W.; Cox, N.; Daughney, C.J.; Wheeler, D. and Moreau, M. (2015) - A national assessment of the potential linkage between soil, and surface and groundwater concentrations of phosphorus. Journal of the American Water Resources Association, vol. 51, n. 4, p. 992-1002. http://dx.doi.org/10.1111/1752-1688.12337
Mehlich, A. (1984) - Mehlich 3 soil test extractant A modification of Mehlich 2 extractant. Communications in Soil Science and Plant Analysis, vol. 15, n. 12, p. 1409-1416.

http://dx.doi.org/10.1080/00103628409367568

Ministério da Agricultura, do Desenvolvimento Rural e das Pescas (1997) - Código de boas práticas agrícolas para a protecção da água contra a poluição com nitratos de origem agrícola. Lisboa, Auditor de Ambiento do Ministério da Agricultura, do Desenvolvimento Rural e das Pescas ed., 52 p.

Mohan, G. R.; Gadekar, S. and Pullammanappallil, P. (2011) - Development of a process model for recovery of nutrients from wastewater by precipitation as struvite. Florida Water Resources Journal, January 2011, p. 17-22.

Olsen, S.; Cole, C.; Watanabe, F. and Dean, L. (1954) - Estimation of available phosphorus in soils by extraction with sodium bicarbonate. United States Department of Agriculture, Circular Nr. 939, Washington, DC.

P-REX policy brief, March 2015. In: Scope Newsletter 2015. [cited 2015-09-30].

http://prex.eu/uploads/media/P-REX_Policy_ Brief_final.pdf

Proposed EU fertiliser regulation criteria for recovered struvite (2015) - [cited 2015-09-17]. http://www.phosphorusplatform.eu/images/ download/ESP P \%20struvite\%20FR\% 20 criteria\%20proposal\%20sent $\% 2024-4-15$.pdf

Reddy, D.D.; Rao, A.S.; Reddy, K.S. and Takkar, P.N. (1999) - Yield sustainability and phosphorus utilization in soybean-wheat system on vertisols in response to integrated use of manure and fertiliser phosphorus. Field Crop Research, vol. 62, n. 10, p. 181-190.

http://dx.doi.org/10.1016/S0378-4290(99)00019-2

Reddy, D.D.; Rao, A.S. and Rupa, T.R. (2000) - Effects of continuous use of cattle manure and fertiliser phosphorus on crop yields and soil organic phosphorus in a vertisol. Bioresearch Technology, vol. 75, n. 2, p. 113-118.

http://dx.doi.org/10.1016/S0960-8524(00)00050-X

Rowe, H.; Withers, P.J.A.; Baas, P.; Chan, N.I.; Doody, D.; Holiman, J.; Jacobs, B.; Haigang, L.; MacDonald, G.K.; McDowwel, R.; Sharpley, A.N.; Shen, J.; Taheri, W.; Wallenstein, M. and Weintraub, M. (2015) - Integrating legacy soil phosphorus into sustainable nutrient management strategies for future food, bioenergy and water security. Nutrient Cycling in Agroecosystems, in press.

http://dx.doi.org/10.1007/s10705-015-9726-1

Runge-Metzger, A. (1995) - Closing the cycle: 
obstacles to efficient $P$ management for improved global food security. In: SCOPE 54 - Phosphorus in the global environment - transfers, cycles and management, $462 \mathrm{p}$.

Salomon, E.; Akerhielm, H.; Lindahl, C. and Lindgren, K. (2007) - Outdoor pig production fattening at two Swedish organic farms - Spatial and temporal load of nutrients and potential environmental impact. Agriculture, Ecosystems and Environment, vol. 121, p. 407-418. http://dx.doi.org/10.1016/j.agee.2006.11.017

Schachtman, D.P.; Reid, R.J. and Ayling, S.M. (1998) - Phosphorus uptake by plants: From soil to cell. Plant Physiology, vol. 116, n. 2, p. 447-453. http://dx.doi.org/10.1104/pp.116.2.447

Scope Newsletter, 2015. European Sustainable Phosphorus Platform. № 111, March 2015. [cited 2015-09-10].

http://www.phosphorusplatform.eu/images/ scope/ScopeNewsletter_111_special_ESPC2.pdf

Sharpley, A.N.; McDowell, R.W. and Kleinman, P.J.A. (2004) - Amounts, forms and solubility of phosphorus in soils receiving manure. Soil Science Society America Journal, vol. 68, n. 6, p. 2048-2057. http://dx.doi.org/10.2136/sssaj2004.2048

Sharpley, A. and Tunney, H. (2000) - Phosphorus research strategies to meet agricultural and environmental challenges of the 21st. century. Journal of Environmental Quality, vol. 29, n. 1, p. 176-181.

http://dx.doi.org/10.2134/jeq2000.004724250 02900010022x

Smith, S. E.; Jakobsen, I.; Grønlund, M. and Smith, F.A. (2011) - Roles of arbuscular mycorrhizas in plant phosphorus nutrition: interactions between pathways of phosphorus uptake in arbuscular mycorrhizal roots have important implications for understanding and manipulating plant phosphorus acquisition. Plant Physiology, vol. 156, n. 3, p. 1050-1057. http://dx.doi.org/10.1104/pp.111.174581

Smith, S.E. and Read, D.J. (1997) - Mycorrhizal symbiosis (2nd edition). San Diego and London, Academic Press, 605 p.

Thompson, L.B.; Mallarino, A.P. and Pecinovsky, K.T. (2012) - Crop response to phosphorus in fertiliser and struvite recovered from corn fiber processing for bioenergy. Iowa State Research Farm Progress Reports. Paper 1948. http://lib.dr.iastate.edu/farms_reports/1948

Torrent, J. (1997) - Interactions between phosphate and iron oxide. In: Auerswald, K.; Stanjek, H. and Bigham, J. M. (Eds.) - Soils and environment.
Advances in GeoEcology, vol. 30. Reiskirchen, Germany, Catena Verlag, 321-344 p.

Torrent, J.; Barberis, E. and Gil-Sotres, F. (2007) - Agriculture as a source of phosphorus for eutrophication in southern Europe. Soil Use and Management, vol. 23, n. S1, p. 25-35.

http://dx.doi.org/10.1111/j.1475-2743.20 07.00122.x

Traoré, O.; Sinaj, S.; Frossard, E. and Van De Kerkhove, J. M. (1999) - Effect of composting time on phosphate exchangeability. Nutrient Cycling in Agroecossystems, vol. 55, n. 2, p. 123-131. http://dx.doi.org/10.1023/A:1009828927161

Vance, C.P.; Uhde-Stone, C. and Allan, D. (2003) Phosphorus acquisition and use: critical adaptation by plants for securing non-renewable resources. New Phytologist, vol. 15, p. 423-447.

http://dx.doi.org/10.1046/j.1469-8137.20 03.00695.x

van Vuuren, D.P.; Bouwman, A.F. and Beusen, A.H.W. (2010) - Phosphorus demand for the 1970-2100 period: a scenario analysis of resource depletion. Global Environmental Change, vol. 20, n. 3, p. 428-439.

http://dx.doi.org/10.1016/j.gloenvcha.2010.04.004

Whalen, J.K.; Chang, C.; Clayton, G.W. and Carefoot, J.P. (2000) - Cattle manure amendments can increase the $\mathrm{pH}$ of acid soils. Soil Science Society America Journal, vol. 64, n. 3, p. 962-966. http://dx.doi.org/10.2136/sssaj2000.643962x

Withers, P.J.A.; van Dijk, K.C.; Neset, T-S.S.; Nesme ,T.; Oenema, O.; Rubæk, G.H.; Schoumans, O.F.; Smit, B. and Pellerin, S. (2015) - Stewardship to tackle global phosphorus inefficiency: the case of Europe. Ambio, vol. 44, n. S2, p. S193-S206. . http://dx.doi.org/10.1007/s13280-014-0614-8

Zapata, F. and Roy, R. (2004) - Use of phosphate rocks for sustainable agriculture. Rome, Food and Agriculture Organization of the United Nations. [cited 2015-09-16]. http://www.fao.org/docrep/007/y5053e/ y5053e00.htm 